\title{
DISTRIBUSI KARBON DI BEBERAPA PERAIRAN SULAWESI UTARA (Carbon Distribution in North Sulawesi Waters)
}

\author{
Nasprianto $^{1,2}$, Desy Maria Helena Mantiri ${ }^{3}$, Terry Louise Kepel ${ }^{4 *}$ \\ Restu Nur Afi Ati ${ }^{4}$ dan Andreas Hutahaean ${ }^{4}$ \\ ${ }^{1}$ Program Pasca Sarjana, Universitas Sam Ratulangi, Gedung B Pasca Sarjana, \\ Jl. Kampus Unsrat Bahu Manado 95115. \\ ${ }^{2}$ Yayasan Pembangunan Berkelanjutan Sulawesi Utara, \\ Kantor Pemerintah Daerah Provinsi Sulawesi Utara, Manado. \\ ${ }^{3}$ Fakultas Perikanan dan Ilmu Kelautan, Universitas Sam Ratulangi, \\ Jl. Kampus Unsrat Bahu Manado 95115. \\ ${ }^{4}$ Pusat Penelitian dan Pengembangan Sumberdaya Laut dan Pesisir, \\ Badan Penelitian dan Pengembangan Kelautan dan Perikanan, \\ Kementerian Kelautan dan Perikanan, Jl Pasir Putih 1 Ancol Timur Jakarta 13440. \\ *Penulis korespondensi. Tel/Fax: 021-64711672/64711654. Email: kepel74@gmail.com. \\ Diterima: 1 April 2015 \\ Disetujui: 8 Juni 2015
}

\begin{abstract}
Abstrak
Provinsi Sulawesi Utara memiliki memiliki letak strategis di mana berada di jalur pelayaran kawasan pasifik serta kawasan segitiga terumbu karang dunia. Berbagai penelitian kelautan telah dilakukan di kawasan ini, namun demikian belum ada informasi ilmiah tentang karbon laut yang sangat penting untuk memahami dinamika fluks karbon dalam kerangka mitigasi perubahan iklim. Tujuan dari penelitian ini untuk menyediakan informasi awal mengenai sebaran karbon di perairan Sulawesi Utara dan menganalisis potensi penyerapan dan pelepasan karbon dioksida $\left(\mathrm{CO}_{2}\right)$ di beberapa perairan Sulawesi Utara. Pengukuran dilakukan secara langsung di lapangan pada parameter $\mathrm{pCO}_{2}$. Pengukuran $\mathrm{pCO}_{2}$ dilakukan di perairan Teluk Buyat, Teluk Totok, Teluk Manado, Selat Lembeh dan perairan Tongkaina. Data-data pCO ${ }_{2}$ hasil pengukuran di perairan Teluk Buyat berkisar 414,17 - 608,29 $\mu$ atm, perairan Teluk Ratatotok berkisar 428,18 -

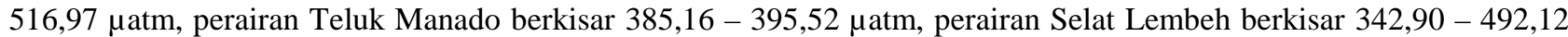
$\mu$ atm dan perairan Tongkaina berkisar 394,54 - 568,32 $\mu$ atm. Nilai $\mathrm{pCO}_{2}$ terendah terletak di perairan teluk Manado sedangkan yang tertinggi terletak di perairan Teluk Buyat. Kisaran hasil pengukuran masih dalam batas normal pengukuran di daerah pesisir yang berkisar antara $200-4.600 \mu \mathrm{atm}$. Hasil analisis $\Delta \mathrm{pCO}_{2}$ Teluk Buyat, Teluk Totok, perairan Tongkaina dan perairan Selat Lembeh berperan sebagai pelepas karbon dan untuk Teluk Manado berperan sebagai penyerap karbon.
\end{abstract}

Kata kunci: karbon, distribusi, pelepas $\mathrm{CO}_{2}$, penyerap $\mathrm{CO}_{2}$, perairan.

\begin{abstract}
North Sulawesi has strategically located in the shipping lanes of the Pacific region as well as in the Coral Reef Triangle. Various marine researches have been done in the area, however, there is no scientific information about the ocean carbon which is essential to understand the dynamics of carbon flux in terms of climate change mitigation. The purpose of this study is to provide preliminary scientific information on the distribution of carbon and to analyze the sink and source potency in North Sulawesi waters. In situ measurements performed on the parameter pCO $\mathrm{CO}_{2}$ Measurements of $p \mathrm{CO}_{2}$ were taken in the waters of Buyat Bay, Totok Bay, Manado Bay, Lembeh Strait and Tongkaina waters. In the waters of Buyat Bay ranged from 414.17 to $608.29 \mu \mathrm{atm}$, Ratatotok Bay ranged from 428.18 to $516.97 \mu a t m$, Manado Bay waters ranged from 385.16 to $395.52 \mu \mathrm{tm}$, Lembeh Strait waters ranged from 342.90 to $492,12 \mu a t m$ and Tongkaina waters ranged from 394.54 to $568.32 \mu \mathrm{atm}$. Lowest $\mathrm{CO}_{2}$ values located in Manado Bay, while the highest in Buyat Bay. Range measurement results are within normal limits measurements in coastal areas ranging from $200-4.600 \mu a t m$. The result of $\Delta \mathrm{pCO}_{2}$ analysis shows that Buyat Bay, Totok Bay, Tongkaina waters and Lembeh Strait relatively act as carbon source and Manado Bay as carbon sink.
\end{abstract}

Keywords: carbon, distribution, source $\mathrm{CO}_{2}$, sink $\mathrm{CO}_{2}$, waters.

\section{PENDAHULUAN}

Perubahan iklim merupakan implikasi dari adanya pemanasan global. Gas rumah kaca, seperti karbondioksida $\left(\mathrm{CO}_{2}\right)$ dan metana $\left(\mathrm{CH}_{4}\right)$ menjadi penyebab utama terjadinya pemanasan global tersebut. Dampak dari perubahan iklim antara lain 
mencairnya es di kutub selatan, pergeseran musim, dan peningkatan permukaan air laut.

Perairan pesisir berperan penting terhadap total budget karbon global karena menerima aliran karbon dan nutrien dari darat dan ekosistem lahan basah walaupun total luasnya lebih kecil dibandingkan laut lepas. Kemampuan ini didukung dengan faktor keberadaan transpor materi dan energi dengan laut lepas melalui continental slope yang menjadikannya salah satu wilayah yang proses biogeokimianya paling aktif. Milliman dan Syvitski (1992) menyebutkan bahwa sebanyak $0,25-0,4 \times 10^{5} \mathrm{~g}$ karbon organik terlarut dilepaskan ke laut dari sungai ke perairan pesisir setiap tahunnya. Pertukaran $\mathrm{CO}_{2}$ antara atmosfer dan perairan pesisir juga terjadi cukup intensif dan mempengaruhi flux $\mathrm{CO}_{2}$ pada skala regional maupun global (Borges dkk, 2005).

Beberapa penelitian menyebutkan kemampuan lautan hingga 48 \% (Sabine dkk, 2004) dalam menyerap $\mathrm{CO}_{2}$. Penelitian lain menyebutkan bahwa dari total 4-5 Pg C yang diemisikan tiap tahun ke atmosfer sekitar 2 Pg C diserap laut, yang kurang lebih setara dengan 50 \%-nya (Cai dkk, 2006). Hasil lain menyebutkan sekitar 90 Gigaton (Gt) karbon/tahun dilepaskan dari permukaan lautan di seluruh dunia, sementara penyerapan tahunan oleh lautan sebesar $92 \mathrm{Gt}$, sehingga terdapat penyerapan bersih $\mathrm{CO}_{2}$ oleh laut sekitar $2 \mathrm{Gt}$ setiap tahunnya (Fletcher dkk, 2006). Rata-rata flux bersih $\mathrm{CO}_{2} \mathrm{di}$ Selat Sunda sebesar $841.603 \mathrm{~mol} \mathrm{CO} \mathrm{C}^{-2}$. jam ${ }^{-1}$ yang menunjukkan pelepasan $\mathrm{CO}_{2}$ dari laut ke atmosfir sedangkan rata-rata flux bersih $\mathrm{CO}_{2}$ dibagian barat Sumatera sebesar $-945.292 \mathrm{~mol} \mathrm{CO}_{2} \mathrm{C}^{-2}$.jam ${ }^{-1}$ yang menunjukkan terjadi penyerapan $\mathrm{CO}_{2}$ di wilayah tersebut (Wahyono, 2011).

Provinsi Sulawesi Utara memiliki letak yang strategis yaitu di tepian pasifik dan termasuk dalam kawasan segitiga terumbu karang dunia dengan wilayah perairan yang luas. Provinsi Sulawesi Utara memiliki garis pantai sepanjang 1.837,29 km, daerah teritorial laut sebesar $161.540 \mathrm{~km}^{2}$ dan kawasan Zone Ekonomi Ekslusif (ZEE) seluas 190.000,00 $\mathrm{km}^{2}$. Kawasan pesisir dan laut yang besar ini menyimpan potensi sumberdaya kelautan dan perikanan termasuk potensi mitigasi perubahan iklim. Namun demikian, belum ada informasi ilmiah tentang kemampuan menyerap karbon di perairan Sulawesi Utara.

Tujuan penelitian ini adalah untuk menganalisis distribusi karbon dioksida $\left(\mathrm{CO}_{2}\right)$ dan menganalisis pelepasan dan penyerapan $\mathrm{CO}_{2}$ di beberapa perairan Sulawesi Utara. Manfaat dari penelitian ini diharapkan dapat memberikan informasi tentang kondisi beberapa perairan di Sulawesi Utara sebagai penyerap dan pelepas $\mathrm{CO}_{2}$ dalam kaitannya dengan perubahan iklim sebagai salah satu faktor yang dipertimbangkan dalam pengelolaan wilayah pesisir dan dapat mengisi kekosongan data $\mathrm{CO}_{2}$ di perairan Sulawesi Utara.

\section{METODE PENELITIAN}

\section{Waktu dan Lokasi}

Penelitian dilakukan pada 15 - 22 Mei 2014 dengan lokasi penelitian sebagai berikut: perairan Teluk Buyat, Teluk Totok, Teluk Manado, Selat Lembeh dan Perairan Tongkaina (Gambar 1). Lokasi yang dijadikan kontrol dalam penelitian ini adalah perairan Tongkaina mengingat kondisi perairan Tongkaina masih alami dan belum ada aktivitas yang padat di perairan tersebut terlihat masih bagusnya kondisi mangrove dan terumbu karang di perairan tersebut. Pada setiap lokasi pengambilan sampel terbagi 6 titik dengan penentuan secara random sampling yang dianggap mewakili daerah tersebut.

\section{Prosedur}

Pengukuran jumlah $\mathrm{CO}_{2}$ di permukaan perairan ( $\mu \mathrm{atm})$ dilakukan secara in situ menggunakan alat Pro-Oceanus System dan untuk data sekunder adalah data jumlah $\mathrm{CO}_{2}$ di udara ( $\left.\mu \mathrm{atm}\right)$ hasil pengukuran yang dilakukan oleh BMKG Stasiun Kototabang Sumatera Barat, Stasiun NOAA di Mauna Loa Hawaii dan skenario perubahan iklim oleh Intergovernmental Panel on Climate Change (IPCC).

Perhitungan Fluks $\mathrm{CO}_{2}$ (bertindak sebagai pelepas atau penyerap) berdasarkan persamaan (1) (Takahashi dkk, 2008).

$$
\Delta p \mathrm{CO}_{2}=p \mathrm{CO}_{2 \text { water }}-p \mathrm{CO}_{2} \text { atmosfer }
$$

Data $\mathrm{CO}_{2}$ atmosfer yang dipakai dalam persamaan ini diambil dari data hasil pengukuran IPCC, BMKG Kototabang dan NOAA yang ketiganya dibuat dalam 3 skenario berbeda. Skenario pertama memakai data dari IPCC tahun 2013 dengan rata-rata kadar $\mathrm{pCO}_{2}$ di atmosfir sebesar 395,72 $\mu$ atm. Skenario kedua memakai data pengukuran $\mathrm{pCO}_{2}$ di stasiun NOAA di Mauna Loa Hawaii, yaitu data rata-rata bulanan waktu pengambilan sampel (Mei 2014) (Anonim, 2015). Skenario ketiga adalah data dari pengukuran $\mathrm{pCO}_{2}$ di Stasiun BMKG Kototabang Sumatera Barat pada bulan Mei 2013 (Anonim, 2014). Apabila hasil perhitungan didapat nilai positif maka diduga berperan sebagai pelepas $\mathrm{CO}_{2}$ sedangkan nilai negatif diduga berperan sebagai penyerap $\mathrm{CO}_{2}$.

\section{HASIL DAN PEMBAHASAN}

\section{Pengukuran $\mathrm{CO}_{2}$ di Beberapa Perairan}

Hasil pengukuran $\mathrm{CO}_{2}$ ditampilkan dalam Gambar 2. Teluk Totok diperoleh hasil yang ber- 

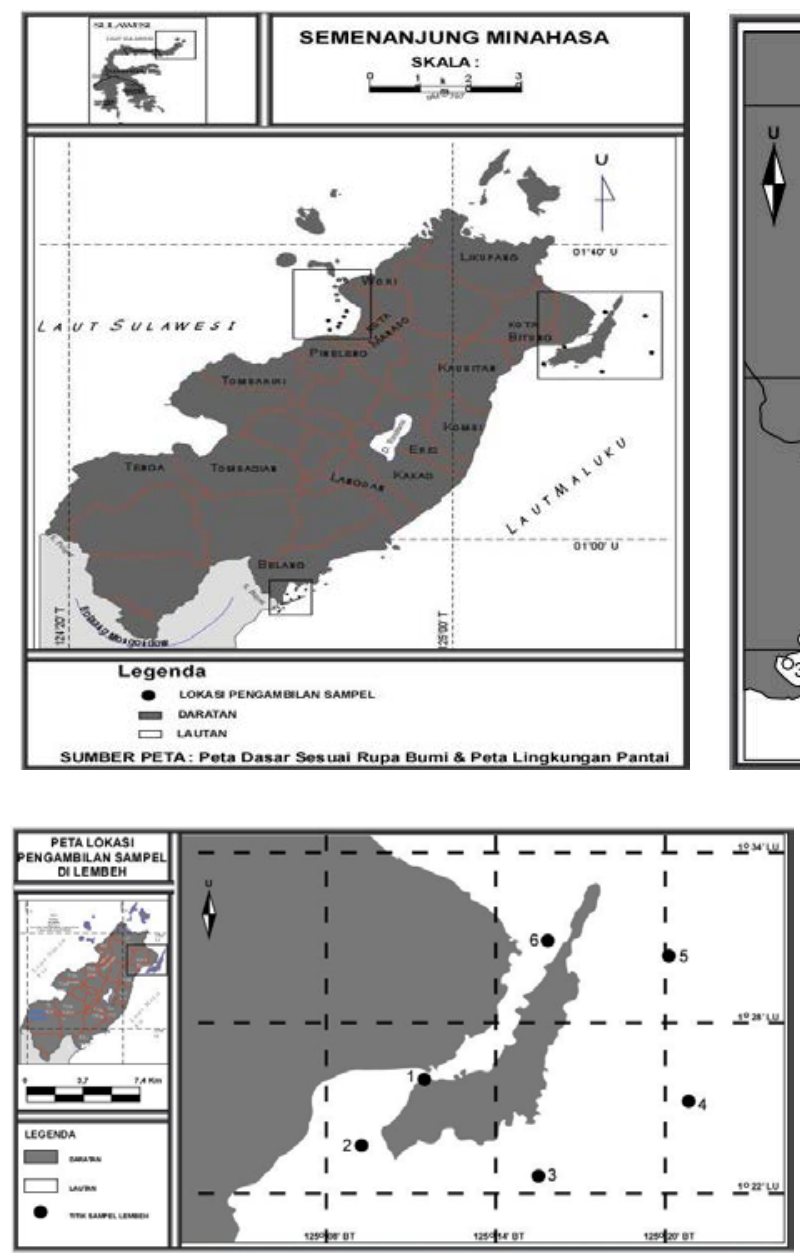

(b)

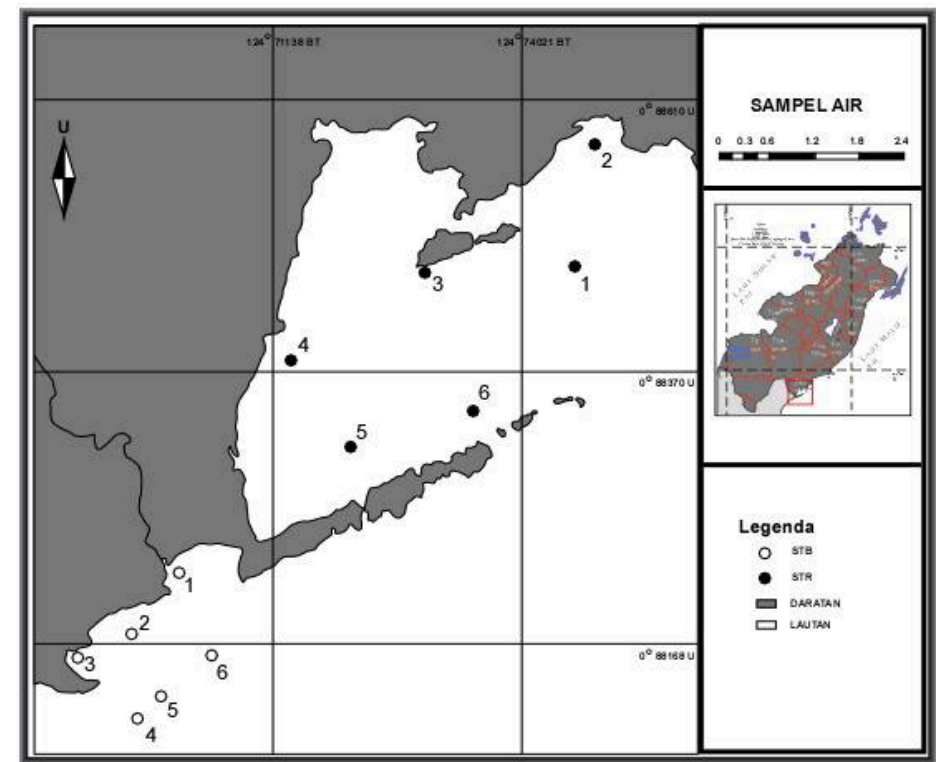

(a)

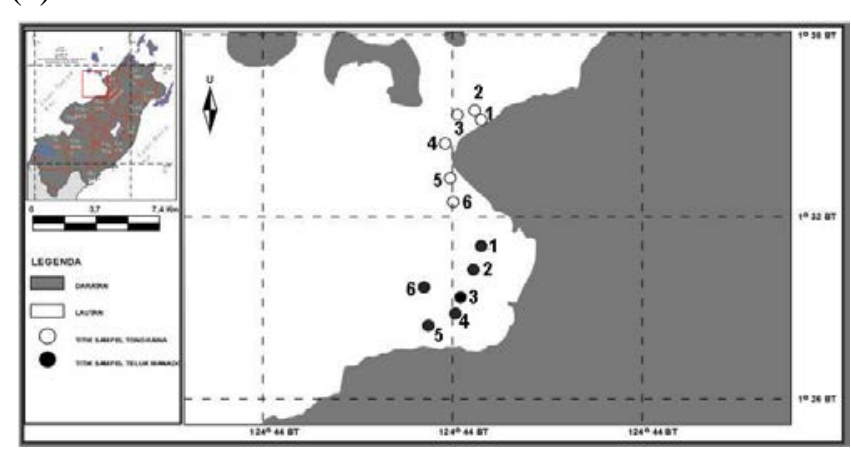

(c)

Gambar 1. Peta lokasi penelitian di (a) Teluk Buyat dan Teluk Totok, (b) Teluk Manado dan Perairan Tongkaina, serta (c) Perairan Selat Lembeh.

kisar antara 432,66-516,97 $\mu$ atm sedangkan hasil pengambilan sampel di Teluk Buyat berkisar 414,17-608,29 $\mu$ atm. Nilai $\mathrm{CO}_{2}$ tertinggi di titik pengambilan sampel berada di Teluk Buyat tepatnya di stasiun 1 dikarenakan letak titik pengambilan sampel tersebut berada tidak jauh dari muara sungai yang diduga pasokan $\mathrm{CO}_{2}$ dari darat cukup tinggi yang masuk ke parairan. Karbondioksida yang terdapat di perairan berasal dari berbagai sumber. Sumber pertama adalah difusi dari atmosfer. Karbondioksida yang terdapat di atmosfer mengalami difusi secara langsung ke dalam air. Sumber kedua adalah air hujan. Air hujan jatuh ke permukaan bumi seara teoritis memiliki kandungan karbondioksida sebesar 0,55-0,60 mg.L1 , berasal dari karbondioksida yang terdapat di atmosfir. Sumber ketiga adalah air yang melewati tanah organik. Tanah organik yang mengalami dekomposisi mengandung relatif banyak karbondioksida sebagai hasil proses dekomposisi. Karbondioksida hasil dekomposisi ini akan larut ke dalam air. Sumber keempat adalah respirasi tumbuhan, hewan dan bakteri aerob maupun anaerob. Respirasi tumbuhan dan hewan mengeluarkan karbondioksida. Dekomposisi bahan organik pada kondisi aerob menghasilkan karbondioksida sebagai salah satu produk akhir (Effendi, 2003). Selain itu dengan banyaknya aktivitas pertambangan liar (PETI) di wilayah Ratatotok dan Buyat yang menjadi salah satu perubahan kadar $\mathrm{CO}_{2}$ yang tinggi bila dibandingkan dengan daerah lain yang menjadi lokasi penelitian. Perairan Selat Lembeh terletak di Kota Bitung, di antara Pulau Lembeh dengan Daratan Sulawesi Utara. Selat Lembeh secara geografis terletak di antara dua lautan yang luas, Samudra Pasifik dan Laut Maluku. Posisi tersebut dipengaruhi oleh pergerakan massa air dalam jumlah besar dari Samudra Pasifik ke Samudra Hindia dan sebaliknya. Pergerakan massa air tersebut ketika melewati Selat Lembeh, yang merupakan sebuah selat yang relatif sempit dengan jarak tersempit kurang dari 800 meter akan menimbulkan arus yang cukup kuat. Selat Lembeh mempunyai panjang sekitar $16 \mathrm{~km}$ dan lebar rata-rata $1-2 \mathrm{~km}$ dengan kedalaman bervariasi dari 0-70 meter, dengan rata-rata kedalaman $15-20$ meter. Bahkan daerah-daerah di sekitar Batuangus kedalaman mencapai $80 \mathrm{~m}$ (Kinnaird, 2002). Kisaran nilai $\mathrm{CO}_{2}$ di perairan Selat Lembeh berkisar antara 342,9- 


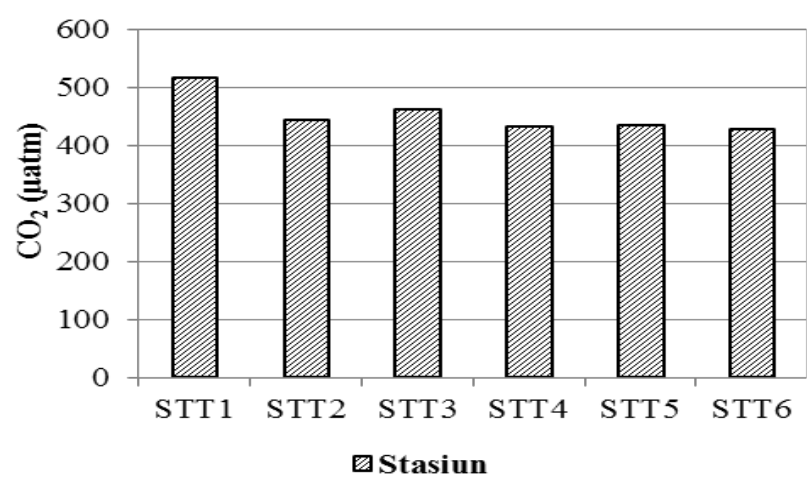

(a)

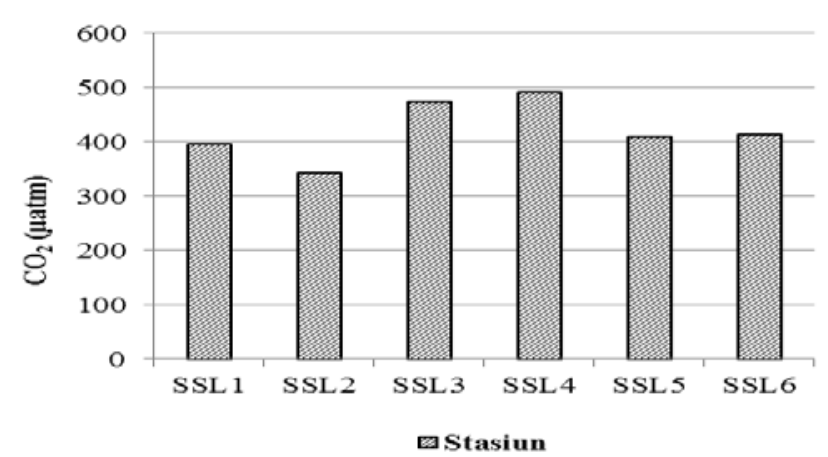

(c)

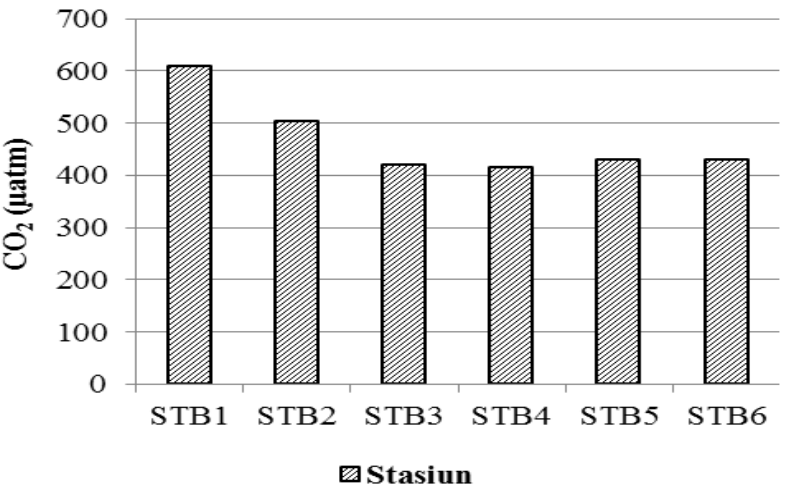

(b)

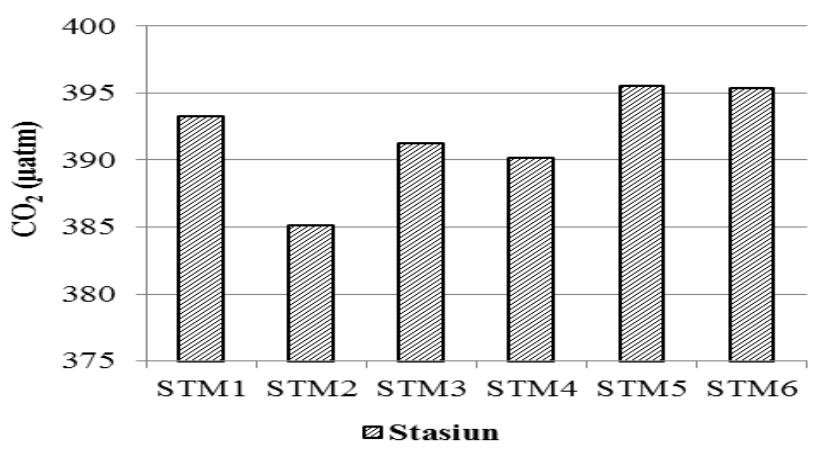

(d)

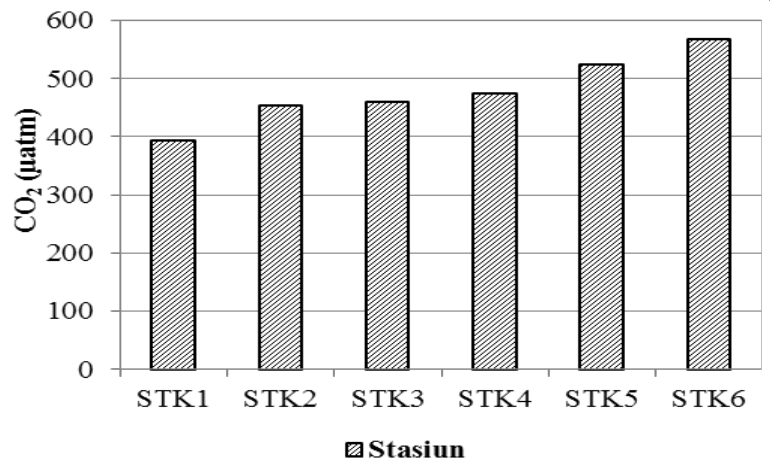

(e)

Gambar 2. Hasil pengukuran $\mathrm{CO}_{2}$ (a) Teluk Totok, (b) Teluk Buyat (c) Perairan Selat Lembeh, (d) Teluk Manado, dan (e) Perairan Tongkaina.

492,12 $\mu$ atm dan nilai $\mathrm{CO}_{2}$ tertinggi berada di stasiun 4 sedangkan terrendah berada di stasiun 2 .

Kota Manado dengan segenap aktivitas dan pemukimannya serta derap pembangunan yang sangat intensif, berada di kawasan pesisir Teluk Manado. Nilai $\mathrm{CO}_{2}$ tertinggi di Teluk Manado berada di stasiun 5 dengan nilai 395,52 $\mu$ atm sedangkan nilai terrendah 385,16 $\mu$ atm berada di stasiun 2.

Nilai $\mathrm{CO}_{2}$ terendah di perairan Tongkaina berada di stasiun 1 dengan nilai 394,54 $\mu$ atm sedangkan nilai $\mathrm{CO}_{2}$ tertinggi berada di stasiun 6 dengan nilai 568,32 $\mu$ atm. Nilai $\mathrm{CO}_{2}$ yang tinggi di stasiun 6 dikarenakan lokasinya yang sangat dekat dengan salah satu muara sungai yang berada di Teluk Manado.

Dari beberapa lokasi pengambilan sampel dapat diasumsikan salah satu sumber karbon yang ada di perairan berasal dari darat. Karbon (organik dan anorganik) yang diperoleh dari daratan juga masuk ke samudera melalui sungai-sungai dan perairan sekitarnya. Transpor ini meliputi transpor karbon alami bersama-sama dengan gangguan antropogenik lainnya. Transpor alami karbon global dari sungai ke samudera adalah sekitar 0,8 Pg C/th, separuhnya terdiri dari material organik dan separuhnya lagi anorganik (Meybeck, 1993). Fluks karbon tambahan dalam kaitan dengan aktivitas manusia diperkirakan sekitar 0,1 PgC/ th yang sebagian besar adalah karbon organik (Meybeck, 1993). Sebagian besar karbon organik disimpan dan sebagian lain digunakan untuk respirasi dengan luaran gasnya kembali ke daratan. Luaran gas karbon antropogenik dari muara cukup besar bila dibandingkan dengan perkiraan emisi $\mathrm{CO}_{2}$ regional, seperti 5 - 10\% untuk Eropa Barat (Frankignoulle dkk, 1998).

Sumber karbon utama di perairan pesisir berasal dari atmosfer, selain itu juga dapat berasal 
dari perubahan sedimen secara terus-menerus dan kandungan nutrisi berupa transpor sumber energi dan materi karbonat ke perairan pesisir baik melalui aliran sungai maupun interaksi dengan laut lepas (Milliman dan Syvitski, 1992). Peningkatan konsentrasi $\mathrm{CO}_{2}$ atmosfer ini berimbas pada keseimbangan konsentrasi dan tekanan parsial $\mathrm{CO}_{2}$ permukaan laut (Takahashi dkk, 2008), sehingga dapat mempengaruhi karbon anorganik dan organik lautan.

\section{Potensi Penyerap dan Pelepas $\mathrm{CO}_{2}$ di Beberapa Perairan Sulawesi Utara Secara Spasial}

Untuk mendapatkan suatu kesimpulan mengenai potensi beberapa perairan di Sulawesi Utara sebagai penyerap $\mathrm{CO}_{2}$ atau pelepas $\mathrm{CO}_{2}$ maka dibuatlah beberapa skenario (Tabel 1), di mana hasil pengukuran $\mathrm{pCO}_{2}$ laut dikurangi dengan $\mathrm{pCO}_{2}$ atmosfir berdasarkan data dari skenario yang ada. Adapun hasil pengukuran $\mathrm{pCO}_{2} \quad\left(\Delta \mathrm{pCO}_{2}\right)$ di beberapa perairan Sulawesi Utara disajikan pada pada Tabel 1.

Berdasarkan Tabel 1 dapat dilihat bahwa dari Skenario 1 di mana hasil pengukuran $\mathrm{pCO}_{2}$ di perairan Teluk Totok dikurangi dengan rata-rata $\mathrm{pCO}_{2}$ atmosfir menggunakan data Protokol Kyoto tahun 2013 dengan rata-rata kadar $\mathrm{pCO}_{2}$ atmosfir sebesar 395,72 $\mu$ atm maka perairan Teluk Totok berperan sebagai pelepas karbon. Hal ini dikarenakan hasil perhitungan $\Delta \mathrm{pCO}_{2}$ positif. Nilai rata-rata $\Delta \mathrm{pCO}_{2}$ tertinggi berada di stasiun 1 dengan kisaran nilai 121,25 $\mu$ atm sedangkan nilai rata-rata $\Delta \mathrm{pCO}_{2}$ terrendah berada pada stasiun 6 dengan kisaran nilai 32,46 $\mu$ atm. Jika dilihat dari Skenario 2, di mana hasil pengamatan dari 6 stasiun perairan Teluk Totok dikurangi rata-rata $\mathrm{pCO}_{2}$

Tabel 1. Skenario Teluk Totok, Teluk Buyat, Perairan Selat Lembeh, Perairan Tongkaina dan Teluk Manado sebagai pelepas (positif $\Delta \mathrm{pCO}_{2}$ ) atau penyerap $\mathrm{CO}_{2}$ (negatif $\Delta \mathrm{pCO}_{2}$ ), dan $\Delta \mathrm{pCO}_{2}$ dihitung menggunakan persamaan 1.

\begin{tabular}{|c|c|c|c|c|c|}
\hline Lokasi & $\begin{array}{c}\text { Hasil pengukuran } \\
\text { ( } \mu \mathrm{atm})\end{array}$ & $\begin{array}{c}\text { Skenario } 1 \\
\text { (395,72 } \mu \mathrm{atm})\end{array}$ & 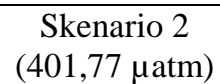 & $\begin{array}{c}\text { Skenario } 3 \\
\text { (392,51 } \mu \mathrm{atm})\end{array}$ & Keterangan \\
\hline \multicolumn{6}{|c|}{ Teluk Totok } \\
\hline STT1 & 516,97 & 121,25 & 115,20 & 124,46 & Pelepas \\
\hline STT2 & 443,57 & 47,85 & 41,80 & 51,06 & Pelepas \\
\hline STT3 & 460,78 & 65,06 & 59,01 & 68,27 & Pelepas \\
\hline STT4 & 432,76 & 37,04 & 30,99 & 40,25 & Pelepas \\
\hline STT5 & 434,79 & 39,07 & 33,02 & 42,28 & Pelepas \\
\hline STT6 & 428,18 & 32,46 & 26,41 & 35,67 & Pelepas \\
\hline \multicolumn{6}{|c|}{ Teluk Buyat } \\
\hline STB1 & 608,29 & 212,57 & 206,52 & 215,78 & Pelepas \\
\hline STB2 & 502,77 & 107,05 & 101,00 & 110,26 & Pelepas \\
\hline STB3 & 420,46 & 24,74 & 18,69 & 27,95 & Pelepas \\
\hline STB4 & 414,17 & 18,45 & 12,40 & 21,66 & Pelepas \\
\hline STB5 & 430,55 & 34,83 & 28,78 & 38,04 & Pelepas \\
\hline STB6 & 430,54 & 34,82 & 28,77 & 38,03 & Pelepas \\
\hline \multicolumn{6}{|c|}{ Perairan Selat Lembeh } \\
\hline SSL1 & 395,09 & $-0,63$ & $-6,68$ & 2,58 & Penyerap dan pelepas \\
\hline SSL2 & 342,9 & $-52,82$ & $-58,87$ & $-49,61$ & Penyerap \\
\hline SSL3 & 474,75 & 79,03 & 72,98 & 82,24 & Pelepas \\
\hline SSL4 & 492,12 & 96,40 & 90,35 & 99,61 & Pelepas \\
\hline SSL5 & 410,43 & 14,71 & 8,66 & 17,92 & Pelepas \\
\hline SSL6 & 413,3 & 17,58 & 11,53 & 20,79 & Pelepas \\
\hline \multicolumn{6}{|c|}{ Teluk Manado } \\
\hline STM1 & 393,27 & $-2,45$ & $-8,50$ & 0,76 & Penyerap dan pelepas \\
\hline STM2 & 385,16 & $-10,56$ & $-16,61$ & $-7,35$ & Penyerap \\
\hline STM3 & 391,23 & $-4,49$ & $-10,54$ & $-1,28$ & Penyerap \\
\hline STM4 & 390,15 & $-5,57$ & $-11,62$ & $-2,36$ & Penyerap \\
\hline STM5 & 395,52 & $-0,20$ & $-6,25$ & 3,01 & Penyerap dan pelepas \\
\hline STM6 & 395,38 & $-0,34$ & $-6,39$ & 2,87 & Penyerap dan pelepas \\
\hline \multicolumn{6}{|c|}{ Perairan Tongkaina } \\
\hline STK1 & 394,54 & $-1,18$ & $-7,23$ & 2,03 & Penyerap dan pelepas \\
\hline STK2 & 455,2 & 59,48 & 53,43 & 62,69 & Pelepas \\
\hline STK3 & 460,48 & 64,76 & 58,71 & 67,97 & Pelepas \\
\hline STK4 & 476,14 & 80,42 & 74,37 & 83,63 & Pelepas \\
\hline STK5 & 524,43 & 128,71 & 122,66 & 131,92 & Pelepas \\
\hline STK6 & 568,32 & 172,60 & 166,55 & 175,81 & Pelepas \\
\hline
\end{tabular}

Sumber : Hasil pengukuran. 
atmosfir dari data di stasiun NOAA di Mauna Loa Hawaii tahun 2015 sebesar 401,77 $\mu$ atm maka perairan Teluk Totok berperan sebagai pelepas karbon dengan nilai $\Delta \mathrm{pCO}_{2}$ tertinggi berada stasiun 1 berkisar 115,20 $\mu \mathrm{atm}$ sedangkan nilai $\Delta \mathrm{pCO}_{2}$ terrendah berada di stasiun 6 dengan kisaran 26,41 $\mu$ atm dan jika di kurangi dengan rata-rata hasil pengukuran $\mathrm{pCO}_{2}$ atmosfir dari data BMKG Kototabang Sumatera Utara pada bulan Mei 2013

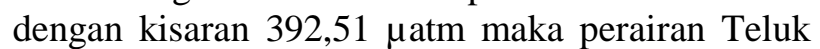
Totok berperan sebagai pelepas karbon dengan nilai $\Delta \mathrm{pCO}_{2}$ tertinggi berkisar $124,46 \mu \mathrm{atm}$ pada stasiun 1 dan terrendah berkisar 35,67 $\mu$ atm pada stasiun 6 .

Berdasarkan Tabel 1, perairan Teluk Buyat berperan sebagai pelepas karbon sama dengan perairan Teluk Totok di mana loaksi kedua perairan tersebut saling berdekatan, dari hasil perhitungan $\triangle \mathrm{pCO}_{2}$ dengan membandingkan $\mathrm{pCO}_{2}$ air dan $\mathrm{pCO}_{2}$ udara dengan menggunakan 3 skenario diperoleh nilai $\Delta \mathrm{pCO}_{2}$ positif. Berdasarkan hasil perhitungan $\triangle \mathrm{pCO}_{2}$ untuk skenario 1 nilai tertinggi berkisar 212,57 $\mu \mathrm{atm}$ pada stasiun 1 sedangkan nilai terrendah berada di stasiun 4 dengan kisaran nilai 18,45 $\mu \mathrm{atm}$, skenario 2 diperoleh nilai tertinggi dengan kisaran 206,52 $\mu$ atm pada stasiun 1 dan nilai terrendah dengan kisaran 18,69 $\mu$ atm pada stasiun 4, sedangkan skenario 3 nilai tertinggi berada di stasiun 1 satu dengan kisaran nilai 215,78 $\mu$ atm dan terrendah pada stasiun 3 dengan kisaran nilai 21,66 uatm.

Nilai $\Delta \mathrm{pCO}_{2}$ di perairan Selat Lembeh lebih bervariasi jika dibandingkan dengan perairan Teluk Totok dan Teluk Buyat di mana perairan Selat Lembeh dapat berperan sebagai penyerap atau pelepas karbon, hal ini telihat dari Tabel 2, di mana stasiun 1 pada skenario 1 dan 2 diperoleh nilai negatif atau sebagai penyerap karbon dengan kisaran $-0,63 \mu \mathrm{atm}$ (nilai penyerap karbon terendah) dan 6,68 $\mu$ atm sedangkan pada skenario 3 diperoleh nilai positif atau sebagai pelepas karbon dengan kisaran nilai 2,58 $\mu$ atm (nilai pelepas karbon terrendah). Dari stasiun 2 diperoleh nilai negatif dari ketiga skenario yang digunakan di mana pada stasiun 2 pada skenario 2 diperoleh kisaran nilai -58,87 $\mu$ atm yang merupakan nilai penyerap karbon tertinggi, sedangkan stasiun 3-6 diperoleh nilai positif atau sebagai pelepas karbon dengan kisaran nilai tertinggi sebesar 99,61 $\mu$ atm.

Perairan Teluk Manado lebih berperan sebagai penyerap karbon karena berdasarkan hasil perhitungan $\Delta \mathrm{pCO}_{2}$ dari 6 stasiun dan 3 skenario yang digunakan diperoleh lebih banyak nilai negatif atau penyerap karbon dengan kisaran nilai tertinggi -16,61 $\mu \mathrm{atm}$ (stasiun 2; skenario 2) sedangkan terrendah dengan kisaran nilai -0,20 $\mu$ atm (stasiun 5; skenario 1). Perairan Teluk Manado yang berperan sebagai pelepas karbon hanya terdapat pada stasiun 1 , stasiun 2 dan stasiun 3 pada skenario 3 dengan nilai tertinggi $3,01 \mu \mathrm{atm}$ dan nilai terrendah 0,76 $\mu$ atm.

Walaupun letak Perairan Tongkaina berdekatan dengan Teluk Manado namun berdasarkan perhitungan $\Delta \mathrm{pCO}_{2}$ perairan Tongkaina lebih berperan sebagai pelepas karbon. Nilai tertinggi pada stasiun 6 skenario 3 dengan kisaran nilai 175,81 $\mu$ atm dan terrendah pada stasiun 1 skenario 3 dengan kisaran nilai 2,03 $\mu$ atm sedangkan yang berperan sebagai penyerap karbon hanya terdapat pada 2 stasiun yaitu stasiun 1 skenario 1 dengan kisaran

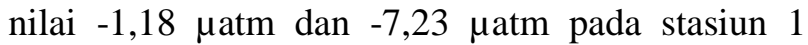
skenario 2. Menurut Bakker dkk (1996), adanya arus dan angin diduga menyebabkan bergeraknya massa $\mathrm{CO}_{2}$ terlarut. Selain faktor cuaca seperti kecepatan angin, arah angin dan curah hujan, maka suhu dan salinitas juga mempengaruhi konsentrasi karbon dioksida terlarut $\left(\mathrm{CO}_{2}\right.$ larut).

Berdasarkan hasil penelitian yang dilakukan oleh Fitranti dkk (2012), di teluk Banten pada tahun 2012 di mana Teluk Banten lebih berperan sebagai penyerap karbon. Hal ini hampir sama dengan yang dilakukan oleh Rustam dkk (2013) bahwa secara umum konsentrasi $\mathrm{CO}_{2}$ di Teluk Banten pada tahun 2010 lebih tinggi dibandingkan dengan kondisi Laut Jawa. Akan tetapi jika dilihat secara lebih detil kepada indikator fungsi $\Delta \mathrm{pCO}_{2}$, maka Teluk Banten pada Maret 2010 secara natural (menurut skenario 1, 2, 3 dan 4) akan bertindak sebagai pelepas $\mathrm{CO}_{2}$ dan sebaliknya akan bertindak sebagai penyerap $\mathrm{CO}_{2}$ untuk Juli 2010.

Penelitian yang dilakukan oleh Afdal dkk (2011), menyebutkan bahwa di Perairan Estuari Donan, Cilacap tahun 2011 bahwa Perairan Estuari Donan berperan sebagai "source" atau pelepas $\mathrm{CO}_{2}$ ke atmosfir dengan kisaran berkisar antara 1018,53 - 1152,52 $\mu \mathrm{atm}$ dengan rata-rata 1077,08 \pm 32,70 ratm. $\quad \mathrm{pCO}_{2}$ dalam kolom air lebih tinggi dibandingkan di atmosfir yang berkisar antara 340 $376 \mu$ atm dengan rata-rata $358,20 \pm 15,27 \mu$ atm dan emisi $\mathrm{CO}_{2}$ terbesar berasal dari bagian hulu estuari dan stasiun yang dekat dengan ekosistem mangrove

Hasil penelitian Cai dkk (2006) dan Borges dkk (2005) secara eksplisit menyatakan bahwa perairan pesisir tropis, utamanya wilayah pertemuan darat laut, termasuk estuari dan mangrove, berperan sebagai pelespas $\mathrm{CO}_{2}$ kuat ke atmosfir dikarenakan input karbon organik dari daratan yang memicu kondisi heterotropik. Namun penelitian Tsunogai dkk (1999) menyatakan bahwa daerah paparan benua, terutama yang dipengaruhi oleh sungai berperan sebagai penyerap $\mathrm{CO}_{2}$.

Sistem pesisir merupakan suatu sistem yang kompleks karena adanya variasi temporal dan 
spasial. Sistem pesisir bisa bersifat heterotrofik ataupun autotrofik. Bersifat heterotrofik karena perairan pesisir menerima pasokan material organik dari daratan, sedangkan bersifat autotrofik karena banyak pasokan nutrien dari darat maupun dari proses upwelling. Dalam banyak sistem, perairan estuari adalah heterotrofik karena besarnya pasokan partikel organik karbon (POC) yang berasal dari daratan. Dalam sistem ini, air selalu sangat jenuh terhadap $\mathrm{CO}_{2}$ di mana tekanan parsial $\mathrm{CO}_{2}\left(p \mathrm{CO}_{2}\right)$ sering lebih tinggi dari $1500 \mu \mathrm{atm}$ dan bahkan melebihi $4000 \mu \mathrm{atm}$ di sungai tercemar (Chen dkk, 2008).

\section{KESIMPULAN}

Berdasarkan hasil pengukuran $\Delta \mathrm{pCO}_{2}$ perairan Sulawesi Utara lebih dominan sebagai pelepas karbon. Selain suhu perairan, tinggi rendahnya nilai pengukuran diperkirakan dipengaruhi oleh masukan material organik maupun inorganik dari daratan ke perairan. Masukan bahan organik dan inorganik yang tinggi ini mungkin disebabkan oleh aktivitas antropogenik yang tinggi di daratan atau daerah pesisir yang mengakibatkan penurunan kualitas ekosistem yang ada. Untuk menghindari penurunan lebih lanjut dari kualitas ekosistem laut dan pesisir ini maka perlu adanya upaya menjaga kelestariannya.

Untuk melengkapai data $\mathrm{CO}_{2}$ di perairan Sulawesi Utara baik secara spasial maupun temporal, perlu dilakukan penambahan lokasi penelitian dan peningkatan frekuensi penelitian sehingga dapat menyempurnakan data $\mathrm{CO}_{2}$ di Sulawesi Utara. Selain itu diperlukan analisis lebih dalam terhadap data oseanografi biokimia dan geofisik di perairan Sulawesi Utara serta keterkaitannya dengan variabilitas fluks Karbon.

\section{UCAPAN TERIMAKASIH}

Penelitian ini adalah hasil kegiatan penelitian bersama antara Yayasan Pembangunan Sulawesi Utara (Surat No. 02a/SP/YPBSU/KET/VI-2013 Tanggal 11 Juni 2013) dan Pusat Penelitian dan Pengembangan Sumberdaya Laut dan Pesisir (P3SDLP), Badan Penelitian dan Pengembangan Kelautan dan Perikanan, Kementerian Kelautan dan Perikanan khususnya pada kegiatan penelitian Karbon Biru tahun 2014 di Teluk Tomini (No. DIPA-032.11.1.634150/2014 tanggal 5 Desember 2013).

\section{DAFTAR PUSTAKA}

Afdal, Panggabean, L.M.G., dan Noerjito, D.R., 2011. Fluks Karbon Dioksida, Hubungannya dengan Produktifitas Primer Fitoplankton di Perairan Estuari Donan. Oseanologi dan Limnologi di Indonesia, 37:323-337.

Anonim, 2014. http://www.gaw-kototabang.com/ hal.php?hal=co2. Diunduh pada Januari 2015.

Anonim, 2015. Up-to-date Weekly Average $\mathrm{CO}_{2}$ at Mauna Loa. http://www.esrl.noaa.gov/gmd/ ccgg/trends/weekly.html. Diunduh pada Januari 2015.

Bakker, D.C.E., de Baar, H.J.W., dan de Wilde, H.P.J., 1996. Dissolved Carbon Dioxide in Dutch Coastal Waters. Marine Chemistry, 55:247-263.

Borges, A.V., Delille, B., dan Frankignoulle, M., 2005. Budgeting Sinks and Sources of $\mathrm{CO}_{2}$ in the Coastal Ocean: Diversity of Ecosystems Counts. Geophysical Research Letters, 32:L14601, DOI:10.1029/2005GL023053.

Cai, W.J., Dai, M dan Wang, Y., 2006. Air-Sea Exchange of Carbon Dioxide in Ocean Margins : A Province Based Synthesis. Geophysical Research Letters, 33:L12603, DOI: 10.1029/2006GL026219.

Chen, C.T.A., Zhai, W., dan Dai, M., 2008. Riverine Input and Air-Sea $\mathrm{CO}_{2}$ Exchanges Near the Changjiang (Yangtze River) Estuary: Status Quo and Implication on Possible Future Changes in Metabolic Status. Continental Shelf Research, 28:1476-1482.

Effendi, H., 2003. Telaah Kualitas Air. Penerbit Kanisius. Yogyakarta.

Fitranti, A.B., Sunarto, Prihadi, J.D., dan Herunadi, B., 2012. Potensi Pelepasan dan Penyerap $\mathrm{CO}_{2}$ Kaitannya dengan Suhu dan Salinitas di Perairan Teluk Banten. Jurnal Akuatika, 2:174-182.

Frankignoulle, M., Abril, G., Borges, A., Bourge, I., Canon, C., Delille, B., Libert, E., dan Theate, J.M., 1998. Carbon Dioxide Emission from European Estuaries. Science, 282:434-436.

Fletcher, S.E.M., Gruber, N., Jacobson, A.R., Doney, S.C., Dutkiewicz, S., Gerber, M., Follows, M., Joos, F., Lindsay, K., Menemenlis, D., Mouchet, A., Muller, S.A., dan Sarmiento, J.L., 2006. Inverse Estimates of Anthropogenic $\mathrm{CO}_{2}$ Uptake, Transport and Storage by the Ocean. Global Biogeochemical Cycles, 20: DOI:10.1029/ 2005GB002530.

Kinnaird, M,F., 2002. Sulawesi Utara. Sebuan Panduan Sejarah Alam. Redikencana, Jakarta.

Meybeck, M., 1993. Riverine Transport of Atmospheric Carbon - Sources, Global Typology and Budget. Water, Air and Soil Pollution, 70:443-463.

Milliman, J.D., dan Syvitski, J.P.M., 1992. Geomorphic/Tectonic Control of Sediment 
Discharge to The Ocean: The Importance of Small Mountainous Rivers. Journal of Geology, 100:525-544.

Sabine, C.L., Feely, R.A., Gruber, N., Key, R.M., Lee, K., Bullister, J.L., Wanninkhof, R., Wong, C.S., Walles, D.W.R., Tilbrook, B., Millero, F.J., Peng, T.H., Kozyr, A., Ono, T., dan Rios, A.F., 2004. The Oceanic Sink for Anthropogenic $\mathrm{CO}_{2}$. Science, 305:367-371.

Rustam, A., Pranowo, S.W., Kepel, L.T., Adi, S.N., dan Hendrajan, B., 2013. Peran Laut Jawa dan Teluk Banten Sebagai Pelepas dan/atau Penyerap $\mathrm{CO}_{2}$. Jurnal Segara, 9:75-84.

Takahashi, T., Sutherland, S.C., dan Kozyr, A., 2008. Global Ocean Surface Water Partial
Pressure of $\mathrm{CO}_{2}$ Database: Measurements Performed During 1968-2007 (Version 2007). Carbon Dioxide Information Analysis Center (CDIAC), Oak Ridge National Laboratory, Tennessee.

Tsunogai, S., Watanabe, S., dan Sato, T., 1999. Is There A "Continental Shelf Pump" for the Absorption of Atmospheric $\mathrm{CO}_{2}$ ? Tellus, Ser. B. 51:701-712.

Wahyono, 2011. Kajian Biogeokimia Perairan Selat Sunda dan Barat Sumatera Ditinjau Dari pertukaran Gas Karbon Dioksida $\left(\mathrm{CO}_{2}\right)$ Antara Laut dan Undara. Fakultas Matematika dan Ilmu Pengetahuan Alam. Universitas Indonesia. Depok. 